\title{
Phillip Blond
}

\section{EMPIRE, NATIONALISM AND CHRISTIANITY}

Phillip Blond, Director, ResPublica, phillip.blond@respublica.org.uk

This paper studies in parallel the history of empire and the development of universals. It uses as its preliminary orientation the work of Eric Voegelin who argued that universals develop in history alongside and through universalising empires. We find this basic contention highly credible as it is empires that force us to develop cognitive approaches that encompass both colonised and coloniser in any subsequent social structure. So conceived, the paper then argues that empires are synonymous with human history as such and that even those entities (such a Greek city states) which are eulogised for escaping this logic are on examination no less imperial than the empires they oppose. The paper then argues that the development of universals is not a byproduct of empire but rather that it drives imperial expansion in the first place. It seeks to argue that ideation is the casual factor in human history, social structures and behaviour. It argues contra thinkers like Francis Fukuyama, there is no biological foundation for the qualitative distinctions of civilisation, rather the paper contends that the origin of civilisation lies in human conceptuality not human biology, locality or indeed any other material force impinging on life. So configured, the paper then concludes that the primary political question lies in bringing together the question of the good with empire - a process most advanced in human history by Christianity.

KeYwords:

Christianity, empire, nationalism, Fukuyama, Greek city states, universals, Voegelin 
Empire is now a much-vilified term. In terms of modern history, it stands in the contemporary mind as a synonym for all manner of evil, the erasure and destruction of difference, illegitimate rule, imperialism, colonialism, etc. In current debate, empire is all too often counterposed to the nation state, which in its turn is understood as the upholder of cultural and national distinction, the only locale of legitimate governance and the site of resistance to imperial incursion.

Paradoxically and incoherently, the defence of nation states contra empires is conducted all too often in a universalist frame, e.g. notions of self-determination that themselves derive from doctrines of rights that are applicable across cultures, time and borders. Those states that inveigh against empires or the EU or any external force that challenges its sovereign autonomy, themselves deploy universalist arguments in doing so. This suggests that after all, there is a conceptuality that overlies, governs and protects their own particularity whilst not deriving from it.

So configured, I argue that there is no defence for particularity or difference or indeed national distinction outside of a universalist argument or idiom. I suggest thereby that for human beings 'universals' are unavoidable, and that all conflict (philosophically at least) is not between universals and particulars but between different notions of a universal, a situation often unbeknownst to the parties involved. I do not mean to suggest a common form of content for such universals in the contests between human beings across all the ages, after all wars are more commonly fought about the nature of the universals in question (and the interests involved thereby) rather than whether there are any such notions. As I will argue that 'universals', from the notions of ruling Gods to that of self-evident rights, are inherent in human symbolisation and self-understanding, I will also contend that they are fundamental to human authority, political legitimation and social order. Their natural social corollary is hierarchical, and either closed and defensive or open and extensive, with a necessary logical tendency to the latter and a sociological tendency to the former. The very idea of justice, for example, is at once universalist but also open and extensive, it implies justice for all and asserts or implies the good. By so doing, the just makes a wider distribution of its own logic (which foregrounds the good) more possible. To oppose 'bad' empires then in the name of justice is simply and rightly to oppose one variant or offshoot of empire to another, not to oppose empire as such.

If one thinks as all ancient people did, that the gods (or more commonly your divinities) control life on earth; that perforce must include commerce with, or power over foreigners. Ancient peoples were aware that others beside themselves existed, and they were equally cognizant that they also had gods who had powers, etc. So conceived it seems inevitable that your governing universal must over time govern (be it negatively or positively) them also. Even if foreigners or the stranger are figured as a threat to be violently countered, it is ideation that is in play not some a priori fixed principle of human interaction. What I am arguing here, is that ideation in large part governs human interaction and that this conceptual generation has inherent within it concepts that apply to more than those that conceive them. I am not of course denying that structures and systems are in play in human history that impacts on the ideation of those born into that history. But I am arguing pace 
Fustel de Coulanges that these self-same material structures are themselves the products of primordial ideational ideas founded exclusively around religion and the Gods. ${ }^{1}$ In short, I am arguing that the so-called material or realist pressures surrounding state formation and group identity are themselves not material but ideal in origin and nature.

In parallel, I also want to suggest that Empire is no late-stage contingent formation of the human species but that its history (for good and for ill) is continuous with human history and in large part the formation and drive of Empire is what has formed and driven human development over time. It appears that both history and archaeology support this latter contention for when looking at the history and evolution of state structure, there appears no real intermediate or wholly autonomous city state stage - we go largely from tribes or chieftainates to 'petty states' that rule by suzerain-vassal relations to empires, and it is the often perpetual competition for dominance between these smaller states that produce empires. It is also the contest between empires and those smaller entities on the edge of empires that often generates empire formation in response. What there does not seem to be, apart from perhaps very geographically isolated tribes, is any stable historical formation around any single self-enclosed identity. Take for example the Greek city states - contrary to the oft perceived sense of their stability, autonomy and continuity - these entities were in a state of almost permanent war as their environment far from being stable was one of persistent anarchy with no international order or binding agreements other than the volatility of self-interest and ever shifting perceptions of military opportunity. The responses of these states to this situation can only really be understood as imperial - since they all sought the elimination and subjugation of their enemies and all sought to dominate and control territory beyond their domain for the sake of the expansion and security of that domain. An anarchic state system can persist for a very long time as the Greek situation readily attests. But the idea that they can be so easily separated from the logics of empire that dictated their near abroad is conceptually fanciful. After all, in this fierce multipolar system certain city states did threaten and then achieve dominance only to lose it again for lack of scale and mass (not will) to enforce their rule. Sparta had its Peloponnesian League in the $6^{\text {th }}$ century, this was challenged by Athens and its empire in the $5^{\text {th }}$ century, a conflict that ultimately ended in Spartan victory, but they were unable to enforce their will over the Greek world and the $4^{\text {th }}$ century ushered in yet more violent internecine warfare that was if anything worse than what had gone before.

As Arthur Eckstein points out in his magisterial study of this period, imperial activity between the Greek polities was often motivated by fear rather than greed - fear of what the ever-shifting tides of alliances may bring to bear against the weak prompted imperial

See Numa Denis Fustel de Coulanges, The Ancient City: A Study on the Religion, Laws and Institutions of Greece and Rome (Baltimore-London: The John Hopkins University Press, 1980). The reader will know how powerful and compelling Fustel de Coulanges's work still is in regard to showing the religious origin of all ancient practices, codes, laws and behaviours. Despite this book being first published in 1864, the most recent scholarship only conforms his original thesis. 
behaviour by both the weak and the strong. ${ }^{2}$ But fear is as equally ideational as avarice, and both are governed by concepts and perceptions of the human mind.

All human societies that emerge from tribal structures do so into state-like formations, and these seem to engage in and form entities that either mimic quasi-federal, and hence empire-like structures, in defiance of larger entities and/or they themselves also form imperialistic missions, colonies and outposts.

So the idea of an ancient city state that exists without (attempted) annexation of its neighbours or colonies, that exists apart from any imperial dimensions seems a historical misnomer. Nation states, as scholarship has long shown, are a late modern development often generated out of the collapse of empires and they themselves often aspire beyond themselves to create empires once more, (Germany being a particularly invidious example).

By running these two ideas together, the philosophical or conceptual problem of universals and history of empires as we currently know it, I hope to open up some questions as to the relative merits of empire and the philosophical thought or conceptualisation that it gives rise to. I will draw on the thinking of the great meta-theorists of human civilisation in general and Eric Voegelin in particular. In part because I think his reflections expose the conceptual and historical poverty of nationalism as we currently conceive of it, and of the 'imperial' nature of truth itself and what I take to be its most universal incarnation - Christianity. Why a focus or concluding set of remarks around the latter? Because if both universalism and empire are unavoidable for cognizant human beings, the task is to render that necessity congruent with justice, ethics and truth. And that ultimately is, I would argue, the political project of Christianity.

So, if nationalism is but a phenomenon and outgrowth of empire and a universal frustrated by its containment by notions of race or place, then indeed what on earth to make of Christianity? Introducing Christianity to the opposition between nation state and empire complicates matters. On the one hand, Christianity's traditional indifference in its earlier form, to current rulers (rendering unto Caesar that which is Caesar's) allowed it to spread through the conversion of elite families and various rulers. It did not proclaim subversion in its call for conversion; on the other hand, Christianity is clearly universalist. It upholds a law that judges all lawmakers and a cosmology that holds that it is the truth of everything and so demands that it rules and (ultimately) legislates over everything and everywhere. In point of fact, if Christianity is congruent with any current political formulation (which it is not as Christendom imagines something quite different as its political end), it is far more drawn to empire than it is to a mere localisation, or worse an identification with one ethnic identity, language or place.

Part of this argument is to dismiss the very idea of a Christian nationalism: as if the message of Christ could be reduced to one people defined by a border or a purported race. But really, I argue that Christianity perfects the notion of Empire through the

Arthur M Eckstein, Mediterranean Anarchy, Interstate War and the Rise of Rome (California: University of California Press, 2006), 48-57. 
notion of justice. A Christian Empire would on this account maintain rather than erase difference and national distinction. To say this is to say that cosmopolitanism in the form of globalised economic and social liberalism usually wins because it rightly uses the language and practices of the universal to mimic truth and justice but manifestly fails to deliver either. To prevail against such, it is imperative not to retreat to particularism but rather to properly embrace the language of the universal and not to cede the language and logic of the universally applicable to an ultimately nihilistic and a wholly destructive liberal logic. I am writing this paper for a Hungarian publication in the heart of a middle European polity, a number of members of which (most notably Poland and Hungary) have re-inscribed Christianity in their political offer and who at the same time are attacked for not being liberals by a universalist liberalism. So, it is understandable that they embrace nationalism and particularism as an alternative but as I hope to demonstrate this is a false comfort, to be truly Christian and to truly protect the differences and distinctions which make up a just plurality and a good society, it is necessary to be both Christian and recover or reclaim the universalist position from liberalism. To argue for a re-configured Christian notion of empire would be for a modern nation state, an assertion of a necessary hierarchy (of good over evil for instance) together with an extensive distribution of the rewards thereby attained and an ethical and equitable distribution of all the goods that such a society can engender.

This broadly put is the argument I would like to make. Time and space mean its elucidation in this form must be circumspect, but I hope it will be illuminating, nonetheless.

To return to the argument, if indeed particulars require universals to defend themselves (as I believe they clearly do), then it begs the question as to where universals come from and what type of political organisations can they legitimate and sustain? It also begs the question as to what I mean by universals and to that end one might argue it is an account that applies everywhere regardless of time or space; a concept or speculation that is true regardless of relativity, circumstance or denial; though of course context, situation and history shapes the nature of this discernment and its manifestation and ultimately what we can know. There are clear difficulties projecting this terminology back into history, let alone to the time before Judaism, Socrates or Plato. Yet it is from this very milieu that such thinking first arose, so it cannot be entirely foreign to it.

If then the current empire/nation state debate is a conflict about universals that is itself a debate between or within universals; then it requires us to ask, can we, in our discussion of political legitimacy, ever escape universals? And if not, can we decide between them or better, can we decide between their respective content and claim? This question takes us, as indicated earlier, to the debate as to the nature and history of human civilisation. The discussion of meta-history has a long and influential lineage from Spengler to Toynbee to Karl Jaspers to Christopher Dawson. Eric Voegelin, who is rightly understood within this lineage, believed that all existent cultures on earth come or came with a corresponding cosmology, a belief that all political action and organisation has its roots in a mytho/ religious account of meaning and that that meaning (or universal) is what directs selfunderstanding, political action and organisation. For Voegelin, human action and 
structure emerges from this all-embracing metaphysics cum cosmology and can only be understood in the light of whatever those cultures believed or held to be true.

Configured thus, this suggests that no human culture has ever been without its metaphysics, its cosmology and its ultimate legitimating principles. Reflexively, this in turn moots that the mark of the human was/is to think in terms of 'mythical wholes', suffused with gods and the rules and demands that such a structure places on humans that live under this aegis. Since people, from their first emergence, undoubtedly thought the gods were both real and true, it is not unsurprising to suggest that they lived by divine dictates. Which term we use to characterise this structure, vis à vis the modern/medieval notion of universals from which they undoubtedly emerge, is a difficult task. Voegelin used the terms cosmological and ecumenical to contrast the mythical world views that were relatively closed, such as the world and gods of Athens and that which was open or contained within it other cultures, e.g. the Empire of Persia.

These 'universals' varied in extension and application; they might be just applied to one people or to one place, (we could call this in modern terms a constrained universalism) or they might be extended to all peoples and all places (an unconstrained application of universals such that they apply everywhere), as with the eruption of monotheism, for example.

Coincidentally, we have never discovered any human settlement that was not also marked by the symbolic. It used to be the case that human and Neanderthal campfires were distinguished by archaeologists through the presence of red ochre, which we know the earliest humans used for painting. But in February 2018 in Science magazine, researchers published an account of cave art in Spain that predates the entry of Homo sapiens into Europe by 20,000 years. ${ }^{3}$ The only conclusion that fits with available evidence is that given the age of these paintings, over 64,000 years old, they are of Neanderthal origin. All of which strengthens Voegelin's metaphysical assumption (for unfortunately he never explicated quite why this would be the case - he merely 'asserted' it was, albeit through multiple examinations of different ancient political and religious texts), for it suggests that symbolisation is perhaps as fundamental to the human creature and its immediate ancestors as breathing or eating. Now symbolisation is not necessarily universalisation (as I will go on to explain) but all universalisation is symbolic and the symbolisations we have from the primordial human past do suggest Voegelin's account of mythic wholes. For what is painted and depicted represents as far as one can judge, exactly this.

So, if being human and thinking and acting politically and socially in a 'universal' manner is equi-primordial or at least implied by the very fact of being human, then empire as a political form looks much more natural and far less contingent than its erstwhile progressive critics would argue. For its very logic impels those who operate under such auspices to extend themselves. It would be wrong however, to argue that all such mythic

D L Hoffmann et al., 'U-Th dating of carbonate crusts reveals Neandertal origin of Iberian cave art', Science 359, no 6378 (2018), 912-915. 
wholes correspond to what we term a universal and its social realisation in the form of empire, since there are or rather were, many tribal groups (if one is to judge by their art and symbolisation) that are encompassed by such but entertain no imperial ambitions. It is the transition beyond tribe that seems to engender the universal and the drive to realise it. Apart from Voegelin, I struggle to think of anyone who has aligned (correctly in my view) the often bloody logic of empire with the rise of a universal that ultimately pacifies and domesticates violence. Perhaps the two are so inextricably linked because theoretically one cannot really think the universal unless one is already in commerce with it, e.g. encountering others in a trans or inter-tribal situation. We might better refine our conceptuality by talking about the transition from meaning saturated manifolds that clearly enveloped all human beings to what I call universals. What precise combination of anthropology, social structure and cognitive development first engendered this move remains to be seen. It might well be the intellectual equivalent of the great farming question - why did humans ever leave the nomadic tribal mode of life for the much harder and more brutal regime of settlement and agriculture?

With the above caveats in mind, I do align universalism with empire which I believe is exactly what Voegelin was also arguing. I accept the symbolic beginning that he describes in the New Science of Politics. He wrote that the beginnings of human society were 'a whole little world, a cosmion, illuminated with meaning from within by the human beings who continuously create and bear it as the mode and condition of their self-realisation.. ${ }^{4}$ In its post-axial form this internal monism of the tribe or the people with their own gods is ruptured by a recognition that the gods might also favour others, that our behaviour might fall short of what the gods intended such that their favour accrues elsewhere, or that if our gods are to rule over others as well, how can they continue to be our divinities alone? The opening up to the idea of a transcendent truth in respect of which we might fall short, and the realisation of an empire seem (as Voegelin recognised) to occur together. Insofar as political representation must represent the 'all', then it cannot be the sole possession of one people. This suggests that the cognitive world of the tribe encounters the universal when it moves beyond itself, in perhaps encountering others or a deity that demands something of them in respect of those others. Whatever the cause or inception, political legitimacy in rule over others requires that those others must also be represented in the self-image of that society and therefore in the thinking of the Gods.

For Voegelin, this self-illumination of human society through symbols gives man his sense of place and purpose. 'The symbols express the experience that man if fully man by virtue of his participation in a whole which transcends his particular existence, by virtue of his participation in the xynon, the common.' 5 The nature or understanding of the whole (participation in which is what he shares in common with his fellow creatures) is what varies, not the human symbolic claim to the whole. And humans have always seemed to

Eric Voegelin, The New Science of Politics (University of Chicago Press, 1952), 27.

Ibid. 27-28. 
understand that in order to grasp a part, one must ascertain the whole. What this means is an epistemic, anthropological and ontological thesis, that human symbolic knowledge requires a claim to a whole in order to explain anything at all. To think symbolically is therefore for Voegelin to necessarily progress by degree or epochal shift, to thinking in a universalist idiom. If thinking precedes action and if action repeats and thereby deepens symbolic thinking, then the symbolic order becomes reflected in the ensuing political order. Since for human beings all stable rule must be legitimate, we should not be surprised that a society's order reflects its symbolic ordering and that the political form it takes is the form that ideation and self-understanding suggests.

To argue this is, in contemporary parlance, to suggest something like the following: that prior to a Kantian-like distinction between concept and intuition, the formative experience of ancient or rather pre-modern peoples was of a world undivided by contemporary philosophical or conceptual categories. All human beings really did seem to believe they were in a wholly divinised world where the transcendent powers (the gods) might favour them if they behaved according to their universal dictates and values.

Least one think that Eric Voegelin was a peculiar though learned academic outlier, this approach is vindicated by the latest scholarship of the ancient and classical period. Take for instance Greg Anderson's remarkable book published in 2018, The Realness of Things Past. In this work he makes many of the points first raised by Voegelin, not least that modern conceptuality and standards of historiography blinds us to the life world inhabited by pre-modern societies. Athenians, Anderson argues, saw their world 'as a single unitary system of life, a divinely ordered ecology, through which a pantheon of gods sustained a community of humans who pleased them'. ${ }^{6}$

This was more than a tutelary concern, the gods in Athens and indeed arguably at and in every other existent human society of that period, shaped and determined all the principles of material and physical existence. Scholarship suggests there were over 200 deities in Attica in the classical period controlling and licensing all manner of human activity and production. These gods and Athena Polias most eminently, guarded over the health and wellbeing of the polis and secured and made possible all its goods. These gods were, as Anderson puts it, 'the ultimate "governors" of the polis'?

Ritual, which was both ubiquitous and continuous in Athens, was the liaison with the transcendent and inculcation of the gods into daily life. This daily re-enactment allied the interests of humans with those of the immortals and dictated and shaped how humans both ordered themselves internally and externally.

We should not be surprised then that a symbolic world that was so complete as to give ultimate meaning and direction to all life under its aegis would seek to extend itself to regions where it was not known. To uphold a universal so completely in one's own realm means that is unlikely that you would accept its diminution or relegation when confronted

6 Greg Anderson, The Realness of Things Past: Ancient Greece and Ontological History (Oxford University Press, 2018), 138.

Ibid. 152 . 
by another universal form in the shape of another city or empire. And in terms of drawing parallels, there appears to be so little between the formation of city states and the formation of empires that one might question (to return to earlier remarks) whether the concepts of an autarkic city state might apply at all. After all, Sparta enslaved another Greek people in the Helots, a people at first thought to be the non-Dorian element in Laconian society and whose population was added to Sparta when Messenia was finally conquered after some twenty years of warfare in 724 B.C. ${ }^{8}$ Plus of course Athens, also engendered an empire towards the $5^{\text {th }}$ century, exercised imperialistic control over the Delian league and was suzerain of 170 other Greek poleis around the Aegean basin during the latter half of the $5^{\text {th }}$ century. It might be ventured that the vaunted self-sufficiency of ancient city states rests on, or reaches to, foundations that are also ineluctably imperial.

By this I do not mean to ignite a historical debate as to the veracity of the concept of a city state but rather to indicate that from the beginning, human beings were aware of the presence of other humans and intellect was forced as a result to fashion concepts that could accommodate other minds and other cultures. As such, the universal is implicated in any cognition of the other even if such cognition denies that universals apply to barbarians, the cognate must be thought for the other culture to fall short, made war upon or be legitimately enslaved. As Thucydides famously said, the 'men are the polis' (andres polis) as such the origin of social structure and ideation is to be found in the minds of men, not in their locale or geographic situation.

And this is perhaps Voegelin's main point. John Milbank has noted in a yet unpublished essay, that Voegelin, like Carl Schmitt, operates in contra-distinction to a medieval mind set where the problem of political representation is that it sits between an order here on earth and an order above in the cosmos. ${ }^{9}$ The medieval task being to align the former with the latter, which Voegelin manifestly fails to do, as he venerates too highly an individuated prophetic or mystical encounter with the transcendent order, and was too pessimistic about a shared social capture of the revelation. Nonetheless, Voegelin understood that it was no accident that the universal itself is generated through universalising empires or even in resistance to and a correction of such empires (as in the case of Israel). What is remarkable about both the traditions of Greece and Israel, contra the reading given by Voegelin is that they each imagine a transcendent good - the weaving of a peace between all nations.

Oddly, Voegelin seems unable to fully grasp the shared nature of universal revelation - it is as if he thinks the experience of the universal is a singular individuated phenomenon that is necessarily betrayed by its transmission and institutionalisation. But nothing about the history of the universal suggests this. Rather, the unfolding of the universal is what leads to law and the extension of its protection and privileges to those who were previously denied such recognition. This expansion of the universal is something that the universal appears to demand, merely by the act of thinking it. We find such in Plato's Laws where he imagines

See L J Piper, 'Spartan Helots in the Hellenistic Age', Ancient Society 15-17 (1984-1986), 75-88.

John Milbank, Truth and the Ambivalence of Empire: On the Theoretical Work of Eric Voegelin. Unpublished paper. 
law transcending the members of one city state and shaping a code that binds all cities and finally brings peace to the warring Greek polities. Similarly, in Genesis, where Judaism says to itself that its task is to be a light to all nations, such that its practice becomes how the rest of the world learns of God. Strangely concomitant with Voegelin's denial that the middle could ever authentically engage with the beginning and the end, is his denial of Platonic, Jewish and Christian mediation, all of which maintain that the uncreated order can filiate with the created order without Gnosticism being the result. As Milbank points out, one can detect in this acutely Protestant valorisation of the revelatory event both the existentialism of the 1950s and bad German biblical criticism. Voegelin fails to understand the deeper Catholic account that revelation reveals relation not rupture, and the communication of such to all other events in time and space.

The essence of the prophetic events that Voegelin eulogises is precisely their communication to and connection with other events. Israel with her union of priest and king and Greece with her Platonic philosopher kings were the key unifying aspects of the Western promise for a just social order on earth and it is exactly this aspect which Christianity aims to deliver in the Church. Which after all is an organisation specifically designed to redeem the earth through bringing it into alignment with heaven. And this legacy in history is so unusual because it was born of this fusion of religion (in its specifically monotheistic Jewish and Christian form) and later Greek philosophy. And both were unprecedented in the way that they understood the cosmos or rather its author as being intimately involved with everyday life and concerned with its fruition and wellbeing. Both as a result presented a universal that was meant to be inculcated here on earth, which meant it had to be communicated to all on earth.

The origin and character of the universal and its impact on human history is often most acutely addressed in meta-history. It is here that one finds the best accounts of the Roman Empire, Christianity and world history. But there are also more contemporary accounts of the universal that find its origin not in ideas or culture but in some version of materialism. It is geography that gives us universals, it is genes, it is sociology, it is anthropology, etc. In the more sophisticated, it is biology admixed with history and anthropology. Perhaps the finest recent example of such occurs in Francis Fukuyama's 2011 classic The Origins of Political Order, when he notes that it is religion that gives us the very idea of a law independent of lawmakers.

Indeed, this text magnifies the issue at hand. Fukuyama has an ascending order of three ideal historical formations which can and do occur separately but when they do so together, they evince for him the ideal political order and they are, respectively: 1 . the state; 2. the rule of law; and 3. accountable government. ${ }^{10}$ He then offers a complex multivalent explanation for the different combinations and origins of the above.

10 Francis Fukuyama, The Origins of Political Order. From Prehuman Times to the French Revolution (London: Profile Books, 2011), 16. 
But serious minds are not content with a multivalent description, however accurate it might be, and some account of why what is selected or historically adopted is required. In this regard, Fukuyama presents us with what I will suggest are two conflicting accounts of the origin of civilisation, or more precisely, two conflicting accounts of what civilisation is. He seems unable to decide if civilisation is just order or a certain type or quality of order. The first is susceptible to an evolutionary explanation the second is not.

Initially at least, the meta-account that explains all others that Fukuyama adopts is conventional, (which does not mean it is wrong) that is, he upholds a weak form of biological causation. For example, Fukuyama argues that humans have four evolved or natural dispositions: we cooperate with kin, we are nepotistic, we are norm followers and we have evolved to be religious. The propelling and unifying force within this framework is the desire for status and recognition that he also suggests is strongly biologically determined.

He writes:

'The primates from which the human species evolved practiced an attenuated form of politics. To understand this, then, we need to go back to the state of nature and to human biology, which in some sense sets the framework for the whole of human politics. ${ }^{11}$ For Fukuyama 'biology presents a certain degree of solid ground', and the above is what it is constituted of. ${ }^{12}$

But then he appears to posit another theory of order:

The huge variance in political forms that we see both at the present time and over the course of history is in the first instance the produce of variance in the physical environments that human beings come to inhabit. As societies ramify and fill different environmental niches across the globe, they develop distinctive norms and ideas in a process known as specific evolution. Groups of humans also interact with each other, and this interaction is as much a driver of change as is the physical environment. ${ }^{13}$

In short, he moves from a biological material theory where human differences are not explained by ideation but by location, to one where interaction with others and their ideas are as determinative as the physical environment is on life. He yet still concludes that 'widely separated human societies have come up with strikingly similar solutions to the problem of political order'. ${ }^{14}$ The range of societies that moved from kinship to monarchy to the

\footnotetext{
Ibid. 25 .

Ibid.

Ibid. 45 .

Ibid.
} 
impersonal administration of a centralised state, is for Fukuyama a 'fact of convergence' that suggests 'an underlying biological similarity'. ${ }^{15}$

There is a question here: Is civilisation form or content? Is the question of political order settled by seeming similarities in structure or opened up by the vast variations in cultural content, behaviour, values and outcomes? Fukuyama seems to equivocate, he accepts that state survival requires legitimacy ${ }^{16}$ and that that is clearly a cultural or ideational issue. In which case the superstructure (if you can forgive the terminology) is determinative of the base. A point he seems to also accept when he stresses that his work focuses on the 'political dimension of development', ${ }^{17}$ and that the values or content of a civilisation can be historically determinative. He accepts for example, that religion can shift society one way or another, he cites India and the rise of Brahmanic religion 2500 years ago as an event that diverted the entire course of a subcontinent. ${ }^{18}$

If the argument is only about order rather than chaos, we might agree that biology favours order and structure over anarchy (since it clearly does) but if the arguments are about the nature and character of that order then it is not so clear that biology or evolutionary theory can explain variation or the differentiation of content in human civilisations. Indeed, the idea that we differ initially and primarily because we live in different places seems odd - especially given the widespread variation in culture and practice that can exist within very small territories that enjoy a similar landscape. And of course, if the theorist wants to say anything in respect of real content, it is the differentiation between and within civilisations that he or she would wish investigated. This seems (rightfully) to be Fukuyama's real intent as he outlines an introductory section where for him the issue is 'Getting to Denmark'. A society that he argues, has pulled off the three aspects of governance that he most values and that he contends secures the type of outcome that we want. But if biology favours order rather than content, which it arguably does, it makes no preference for what type of order it prefers. Whereas human society and human beings are markedly different from the rest of creation as alone amongst the animals they can (as Aristotle noted), change their own nature according to their culture.

Fukuyama in this text at least seems beset by equivocation, at first there is biology then there is not, and the concern is with the origin of order then it is with the type of order originated. Moreover, the four dispensations he says that we have evolved have metaexplanatory power, but do they themselves require more foundational explanation or they are empty? Take for example 'we have evolved to be norm followers' well what norm? And given that even a cursory examination of human history will show wide and varied practice in anything from marriage codes and structures to what constitutes honour, what does such a claim add? It is surely an empty proposition; societies want order, but what order remains undetermined. It is no more an explanation as to the type of political order

Ibid. 46 .

Ibid. 17.

Ibid. 19.

Ibid. 21. 
we have, than the mildly empirical reflection that power tends to centralise. The claim that we have evolved to be religious is another empty proposition, since religions (like the type of political order) vary as wildly and as widely as any human variation on earth. One might as well say we have evolved to think and take that as a solution to the problem of what to think and when. Fukuyama is certainly on stronger ground when talking about nepotism and kin co-operation, but again this just tells us about our tendency to order, rather than what we order and its nature and value. The Origins of Political Order tells us some very valuable things about the origin of order but much less about the origins of political order. Why this society had this structure, why it believed in this type of legitimation and not that? Why it upheld these gods and these practices and not those gods and those practices? So as a history of political ideation and difference, or why we have the political order we do, the book is rather empty description rather than an explanative exercise.

How then might we better explain the variety of political order or better the variance of political legitimation that different societies have? Rather than starting with a material explanation of cultural outcomes, we might be better advised to start with an ideational explanation of different ideological outcomes. If culture emerges with practice which emerges with belief, how are we to explain and expound upon change? Rather than practice leading and ideas following, I suspect that the motive power in human history lies not with sociological accounts of change followed by reflection. Rather, the human mind has the curious and seemingly unique power to negate what lies in front of it (recall Adorno's power of the negative) and recast it according to the imagination. Obviously genuine change is a mixture of all factors, each compounding and complicating the other, but the sheer potency of the symbolic mind coupled with the ability of human collective agency to realise such visions leads me to think (and here I agree with Voegelin) that historical causality or direction has more of a mental than a material basis.

Though you will gather from the preceding that I am arguing that cultures with universals develop a sense of mission and some variant of empire, some do so more extravagantly than others. And given that I wish to argue that empires make a mass, decent society possible, one that cuts across all the divisions that normally plunge human beings into murderous and brutal conflict, I want to examine now where I think that possibility has been most explored and fulfilled. This takes us to Europe and the West, where distinct historical circumstances produced the most open society known in the ancient and classical world - The Roman Empire.

But as Plato had long noted, we human beings are mimetic creatures; we learn by recalling and repeating, and much of Rome was a repetition of Greece in general and Alexander the Great in particular. As Krishan Kumar points out in his text Visions of Empire, it is to Alexander that 'we owe the earliest, most widespread and longest-lasting creation of the idea of empire and of its mission'.19 His empire stretching from the Danube to the

19 Krishan Kumar, Visions of Empire: How Five Imperial Regimes Shaped the World (Princeton University Press, 2017), 45 . 
Indus was founded not upon ideas of exploitation but rather a higher ideation: universality. What we have as historical reportage from his advocates, admirers and chroniclers, all point as Kumar notes, to Alexander's idea of uniting East and West across his lands and producing for the first time a world culture. Not for nothing did he attempt through multiple marriages and many alliances of both himself, his kin and his generals to knit entirely foreign cultures together through the idea of a universalising empire. He asked his Macedonian satraps to adopt local culture of dress and customs and to learn the language of the people they ruled over and to become one with them. That it all broke down after his death is no repudiation of the idea but is a mark of how far the man had advanced ahead of the cultures he tried to unite. The approach and politics of fusion were to be repeated and recapitulated by most sustainable empires henceforth. A fusion that comes, and let us state the obvious, from no material cause that we can determine. Alexander founded his world from his ideas and his ideation, repudiating his teacher Aristotle for whom the non-Greek was nothing but a barbarian.

And the best reading of the origin of these novel ideas of Alexander lies in the scholarship of the British Hellenist William Tarn. First presented in 1933 at the British Academy, Tarn spoke of the extension of Homonoia or 'being of one mind together' by Alexander to all the subjects in his realm - whether Greek or Persian. In his later reflections on this idea, Tarn said Alexander's empire had three distinguishable facets: firstly that 'God is the common father of mankind', secondly 'the unity of mankind', and thirdly that 'the various peoples of his Empire might be partners in his realm rather than subjects'. ${ }^{20}$ As Tarn notes, in Egypt Alexander is reported by Plutarch to have replied to a philosopher who said in homage to Homer that God is the king of all men, Alexander replied God is the father of men not just the king. ${ }^{21}$ This conceptualisation leads inescapably to the second and third facets of Homonoia that Tarn mentions. Alexander did not reach these conclusions after he had conquered. These conclusions are why he conquered.

This universalising mission had enormous symbolic and historical power, not least to the Romans, who regularly attempted a recapitulation and fulfilment of Alexander's symbolic legacy. Aelius Aristides's famous Oration to Rome, presented to the imperial court, concludes with a eulogy to Rome exceeding the Greek legacy in its moral and political character. It is a paean to among other things, Roman order, justice, tranquillity and equality. Rome fulfils Alexander's legacy by creating a 'civil community of the world'. Yes, there is Roman rank and order and hierarchy, (and also slaves) but no free citizen is barred from membership of the highest rank by race, class, religion or location. Even to the level of the Emperor, Hadrian after all was from an Italian family that settled in Spain but despite being from, or rather despite being located in the periphery, he maintained close links with Rome and was elected Emperor by the Senate on Trajan's purported nomination. Interestingly, he was perhaps the most Pan-Hellenic of the Emperors enraptured as he was

20 W W Tarn, Alexander the Great. Volume II. Sources and Studies (Cambridge University Press, 1948), 400.

${ }^{21} \quad$ Ibid. 435-436. 
by Alexander and the Greek ideal. He, like other Caesars, also sought to forge a common unity amongst disparate peoples. So, when Aristides spoke of the Empire engendering a common nationality where 'all paths are open to all [...] and a civil community of the world has been established', he was not speaking into a vacuum. This was the governing ideology of the ruling Roman class, even if it was a deeply unequal and stratified culture and society. The benefits of civilisation were felt by all - regardless of their station. Hence, the Roman mission of civilisation or humanitas, which was felt and experienced to be real both by those who lived in Roman lands and were thus guaranteed peace, and those who wished they did, (often the very barbarians who attacked Roman borders). Rome was the most open society in the ancient and arguably the medieval world, it did not define membership of its polity by race, geography, class or creed. You were not necessarily born into it or on it (unlike the Greeks whose fatal limitation was that they thought only those born in Hellas could sustain civilisation), it was something you could join. Through affiliation to its values, those without membership of the Roman polity could through absorbing and repeating its culture and pledging allegiance be awarded citizenship after due consideration. You could also proceed by degrees - those approaching 'civilised' standards could acquire additional rights and privileges up to and including citizenship. The ius Latii was the pathway to acquire such by increments and degree, offering, as Kumar points out, 'a model for the incorporation of other foreigners and even the most distant barbarians'. ${ }^{22}$

It is beyond remarkable in the ancient and the modern world that conquered peoples were so quickly allowed to participate in the hierarchy of the victorious state. Emperor Caracalla's proclamation in 212 AD that all free subjects would now enjoy full Roman citizenship induced perhaps that most important element of equality in a state: formal full and equal membership. This is most important because once it is formally granted, the reality of enduring inequality loses legitimacy, and rights progressively accrue and distribute. Indeed, much work recently has been done in the contemporary world on the value of being a member of one of the more prosperous and developed states. Its value far exceeds what the average person could conceivably earn - even in those advanced states. One must surmise that something like this would also have pertained within the orbis Romanus.

When the distinction between the conquered and conquering people vanished as it did with the Caracallan proclamation, the Empire moved on again, to use Voegelin's terms, from a relatively closed to an even more open and ecumenical domain. Some have broached that this made Rome a nation state (one people within borders) rather than an Empire, but this claim is misplaced. A nation state has no grand mission other than preserving itself or perhaps in that peculiar blend of nationalism and imperialism - extending itself. But Rome as the holder of and purveyor of universal citizenship would have no theoretical or philosophical impediment from extending the benefits of civilisation even further, to incorporate yet more people and cultures under its auspices and to accept that it is changed

22 Kumar, Visions of Empire, 58-59. 
by this experience such that its expansion does not mean another's subjugation. Once Rome placed universalisation and mission at the core of European self-understanding (which I would suggest is its ultimate legacy), then it made Roman Europe different from almost everywhere else. Which is perhaps why Christianity first took institutional root there.

As argued at the outset, all cultures are saturated with their own meaning. The human mind, in commerce with reality (both mundane and transcendent), fashions the forms that will then shape the social world that people inhabit. At some point this governing, symbolic cosmology encounters something beyond itself, perhaps it is other humans governed by different gods, perhaps it is in that stage and negotiation between human settlement, fortification and warfare? Either way, there appears a dialectical relationship between ideation and empire, between the emergence of universals and imperial expansion and conflict. This relation, one that perhaps only Voegelin has fully confronted, is a difficult one to discern and unpack. One must remember that the imperial surge is not across a field of innocent, wandering subjects in an idyllic state of nature. The reality is, the imperium is often a response to the ongoing series of small but equally lethal local and often fratricidal conflicts within and between closely related tribes and groups. Nor is the universal or the ideation of empire some after-the-fact legitimation of a deeper instinctual drive; this would be to posit a philosophically and historically unsustainable account of human nature as driven to violence. If so, why not violence always, and if so, why the clear preference for peace that humans express time and time again when such peace is secured? The universal tends to the ecumenical, though of course the reality of human expansion and history is also a story of constrained universals or nationalist imperialisms (to use modern terminology), but that notwithstanding it is worth reflecting on Karl Jasper's axial age thesis. Here one could argue that the emergence of religion in the context of empire and expansion is in part an attempt to constrain slaughter by conferring on others a status or taboo that prevents extreme violence. Recall Augustine's arguments in the City of God that so many were spared the sword in the sack of Rome in 410 by Alaric, precisely because Christian practices of sanctuary and mercy were observed by barbarians who had adopted the faith of those they conquered.

And as commentators note, Augustine finds much to admire in Rome, so much so that he takes the benefits of Roman law as self-evident and declares that the establishment of the empire was guided by providence to suppress the violence and discord of nations. The 'virtues' of Rome in The City of God are named via the authority of Sallust, who is quoted in what can only be approval. Sallust names that first Roman 'virtue' as liberty (libertas) or love of country or better yet, a love of the shared life and vision that is Rome. When Romans discover this love, they want it to dominate and rule so they embrace glory as their highest goal. This pursuit of glory (the extension of their love of Rome) leads to conquest (dominatio) and empire. How can we think about this relation between libertas and dominatio for they seem in explicit contradiction. But are they? In a way Rome uncovered what concerned us at the beginning of this essay - a universal that logic and emotion both demanded. The notion of dominance implies that this 'libertas' is indeed good and should rule - and it is better that the good rules than evil. The Roman love of 
glory was the Roman love of their (open) city and for this, they supressed all other vices. However, if it would be too strong to call glory a Christian virtue; it was clearly a pagan one as it suppressed manifold varieties of private vice. Glory for the sake of praise of others, shows that public honour and being ruled by public honour rather than private vice was indeed possible.

I am not attempting an exegesis of Augustine here - I am merely pointing out that even the most profound Christian thinker of the entire classical period discerned what Rome bequeathed to the Christianity that came after. At the outset of the paper, I argued that if universalism is unavoidable for cognizant human beings, so it appears historically in its externalisation: empire. The political task is not to attempt to deny that the ruling history of the world, e.g. that social structure which has governed most human beings for most of civilised history is empire, but rather to render that necessity congruent with justice, ethics and truth.

This presupposes that such a thing as good is a real existent entity. Yet few in the ancient Greek world (apart from the Sophists) denied the presence of a real good in the world, the Academies just differed about its nature and origin. Plato named the existence of good, and further stated that good is beyond all beings, but yet governs, shapes or directs those beings. ${ }^{23}$ As so often with Aristotle, you find that his thinking extends rather than contests Plato. For Aristotle the aim of ethics was to fulfil the 'moral' form that you had been given, the injunction being to become the is that lies like a nascent promise within you. This is, after all, the aim of Aristotelian virtue ethics: to allow one to flourish through becoming what one ought to be. So configured, the Greeks could think henology and plurality, they knew there was a one and a many, but the difficulty for them was the communication and relationship between the two. Why would the absolute care for the creatures it brought into being? Why would it allow its divine nature to be participated in by things that were not divine? Or as Plotinus put it - why was the one not satisfied with itself such that it produced this plenitude of beings? If we are to bring the many into accord with the one, how can we be assured as and when this relationship would be attained? One might say (though this would be unfair to Plato) that the Greeks discovered moral reality (or the necessity of ontological hierarchy) but had no real idea how to distribute it to the many who desperately needed it. Perhaps this is the true source of the Greek's restriction of humanity to themselves? Whereas Rome is really the foundation of the city of the many. Rome from its foundation gradually expanded to the many such that all could enjoy the benefits of civilisation.

So how can these two vectors be together, the pole of the one (Greece) and the pole of the many (Rome)? This is where the Jewish-Christian legacy interpolates and creates the dramatic new fusion or possibility that I spoke of: an empire that is good. The Jews, like Plato, upheld a source of cosmological order and law in the universe - what was so revolutionary about Israel is that this was held to overturn the rule of kings and subject

23 See Plato's Republic, 509B. 
royal to divine authority. Such that all had to obey or live in accordance with God's law. This means there is no site of temporal authority that is separate from or free of the need to abide by divine authority. In which case, one could say 'well that is much the same with polytheistic systems'; but polytheism tends to just be a Feuerbachian projection of existing mundane power narratives, and since these gods are arbitrary and often go to war against each other, they demand little of their subjects except abasement and worship. Jewish and Christian monotheism by contrast makes a requirement that often runs counter to the world and the demands it places on human populations. It limits and changes existent and dominant social practices, it transforms rather than reflects the world in which it originates.

What is the Christian breakthrough in the light of my argument so far? It is, I think, the union of the Greek and Roman poles so that the political issue is both hierarchical and distributive. By this I mean Christianity achieved a settlement that theoretically at least was, and is, for the many and the few. How does Christianity do this? Approaching the philosophy and theology first - Christianity describes the godhead not as substantial and therefore always apart from us but as relational, which is what Trinitarian thinking accomplishes. By describing God as a relational absolute, the creature does not threaten the divinity of the Creator in that relationship. Moreover, by describing the nature of God as love rather than law (and law comes from love), Christianity explains what the Greeks could not, which is why the universal would disclose all of itself in the particular, (though the particular does not exhaust the universal in its exemplification of it). What this means is that we have a Christian realism exemplified of course in the incarnation, whereby every form and every being is divinised and revealed to share in divine self-understanding and existence. So conceived, we are able to philosophically hold together unity and plurality, since the one is already relational and wishes to extend itself as the good that it is.

Now just as Alexander's politics of inclusion and integration follows logically upon his theology, so it is with Christianity. The incarnation divinised all humanity and led directly to St Paul's injunction in Galatians 3:28: 'There is neither Jew nor Greek, there is neither slave nor free, there is neither male nor female; for you are all one in Christ Jesus.' It was and is Christian ontology and theology that established the sheer universality of its universal. It is the most extensive claim and universal mandate - its writ runs across all of creation.

It is the promise of a full participation in the divine life and recovery and renewal of the earth. God creates a unique society in the Church that is beholden to none and chaffs at the very idea of being governed by some other. Something always rules and if it is not the Church which has the ultimate good as its teleology then it is something which is not good governing the good. But good is never disclosed in one entity or one thing. As the medievals would later note, many things represent God better than just one thing. Moreover, since God is fecund and creative, there is no end to the differentiation and plurality that He gives and that also expresses His nature. So paradoxically, the relation between the one and the many is inverted, and it becomes an issue not of direct rule but of discernment - what is in the pattern of the divine and what is not? 
In a way then we already see the shape of a Christian Empire - it has no limit - it accepts no exclusion, it promotes radical equality and equity, for all should flourish. It eschews the distinctions of class, race and place. Yet it is in commerce with a genuine reality that produces an order, a place and a scale that is not unrelated to that of music. Theoretically at least, we can see the shape of an empire that could be good, that is committed to the ethical reality vouchsafed by revelation, just as it is committed to the radical distribution of good to all life. Now time and space prevent me from a longer study of Christian Empire in its historical actuality - but the Pax Christiana was a real force. One can readily recall for example the Pax Dei movement that arose in the late $10^{\text {th }}$ century in France against the tide of rising carnage and disorder. It readily reimposed sanctions on warlords or castellans who through the strongholds of castles were able to defy regional authority and lay waste to their neighbourhoods. This movement of lay congregations and priests was able to limit the number of days for warfare, they also reinscribed taboos against killing women and children and even farm animals. It became part of the institutional framework of the Church and helped to reimpose order in Europe in the $11^{\text {th }}$ century.

Part of what I wanted to argue is that all politics is about universals, and human conflict is both between and within them. Those concerned (often rightly) with defending national distinction usually fail as they restrict the universal to a national and often ethnic basis. What those of us who are opposed to both economic and social liberalism often forget is that liberals do not own the universal. Liberal hegemony has only taken place because we have ceded the universal to them. If liberalism is contested only on the basis of particular self-interest, then post-liberals will always lose. For the counter argument will always draw upon the self-interests of others and the necessity of a liberal state to manage that conflict. Yet the very things most post-liberals want to defend such as Christianity, order and conservation, has in human history only been defended by a more universalist account of what is at stake. We now know that liberal universalism itself only serves a narrow, empowered and self-interested group. Better I think to recover the defence of national difference through the notion of Christian empire that I discussed earlier - here distinction can be defended not as self-interest but as being in the general interest. Paradoxically, it is empire that can best defend and maintain nations, for if nations do not buy into something bigger than themselves, they will just be erased by bigger nations. This after all, is the deep lesson of history. Only Empires preserve difference. 


\section{REFERENCES}

1. Anderson, Greg, The Realness of Things Past: Ancient Greece and Ontological History. Oxford University Press, 2018. Online: https://doi.org/10.1093/oso/9780190886646. 001.0001

2. Coulanges, Numa Denis Fustel de, The Ancient City: A Study on the Religion, Laws and Institutions of Greece and Rome. Baltimore-London: The John Hopkins University Press, 1980.

3. Eckstein, Arthur M, Mediterranean Anarchy. Interstate War and the Rise of Rome. University of California Press, 2006. Online: https://doi.org/10.1525/california/978052 0246188.001.0001

4. Fukuyama, Francis, The Origins of Political Order. From Prehuman Times to the French Revolution. London: Profile Books, 2011.

5. Hoffmann, D L et al., 'U-Th dating of carbonate crusts reveals Neandertal origin of Iberian cave art'. Science 359, no 6378 (2018), 912-915. Online: https://doi.org/10.1126/ science.aap7778

6. Kumar, Krishan, Visions of Empire: How Five Imperial Regimes Shaped the World. Princeton University Press, 2017. Online: https://doi.org/10.1515/9781400884919

7. Milbank, John, Truth and the Ambivalence of Empire: On the Theoretical Work of Eric Voegelin. Unpublished paper. DOI: https://doi.org/10.30965/9783846764879_008

8. Piper, L J, 'Spartan Helots in the Hellenistic Age'. Ancient Society 15-17 (1984-1986), 75-88. Online: https://doi.org/10.2143/AS.17.0.2011373

9. Tarn, W W, Alexander the Great. Volume II. Sources and Studies. Cambridge University Press, 1948.

10. Voegelin, Eric, The New Science of Politics. University of Chicago Press, 1952.

Professor Phillip Blond holds the visiting Chair of Christian Philosophy and Politics at the University of Public Service in Budapest, Hungary. He is also the Director and founder of the British public policy think tank ResPublica which is based in London. His research interests focus around history, anthropology, political philosophy and theology. He authored the book Red Tory in 2010 which started the modern postliberal trend in political philosophy and he has published many articles and reports on public policy which focus on providing both economic and cultural security to the marginalised and unequal. 